
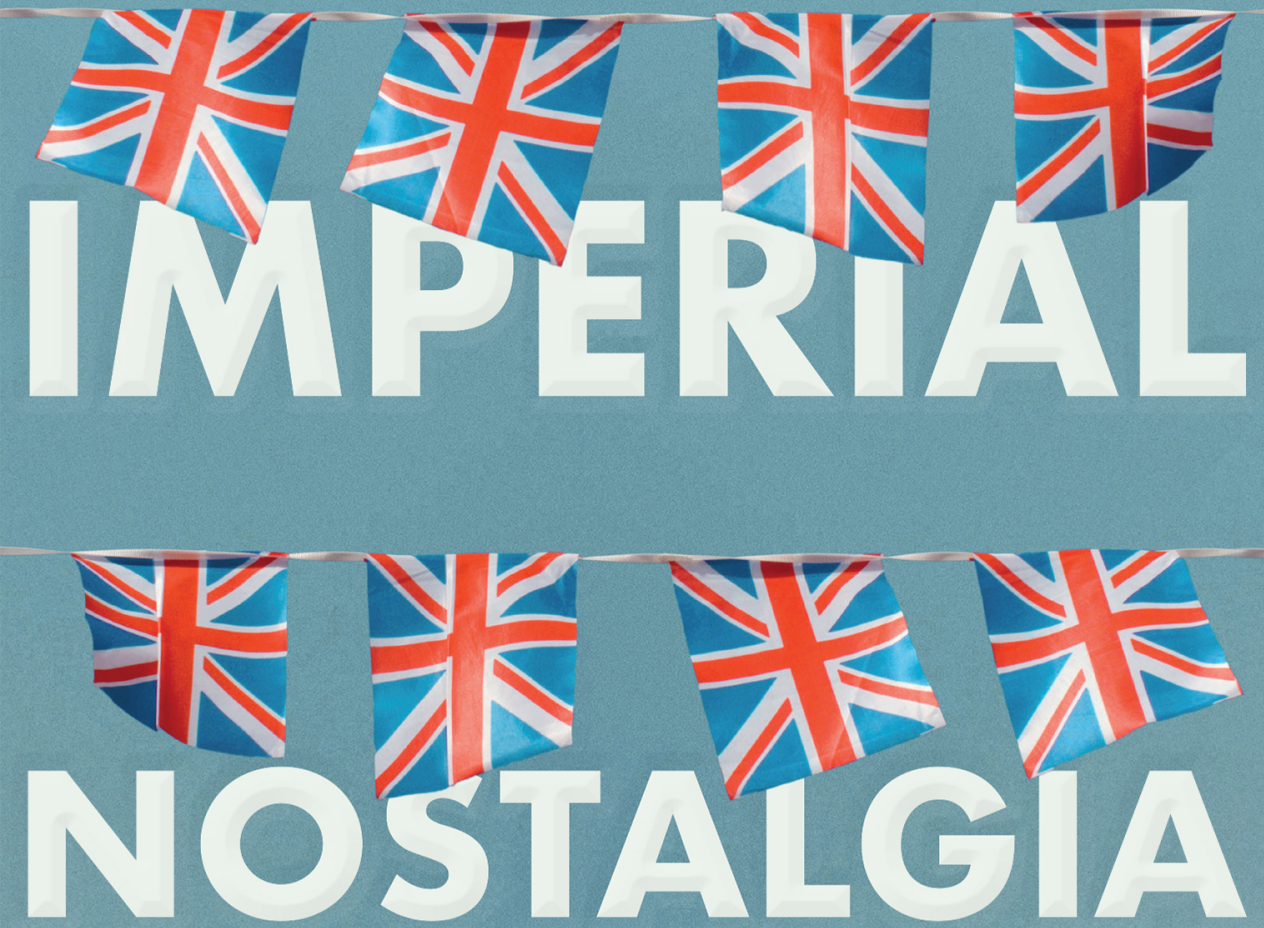

HOW THE BRITISH

\title{
CONQUERED THEMSELVES
}

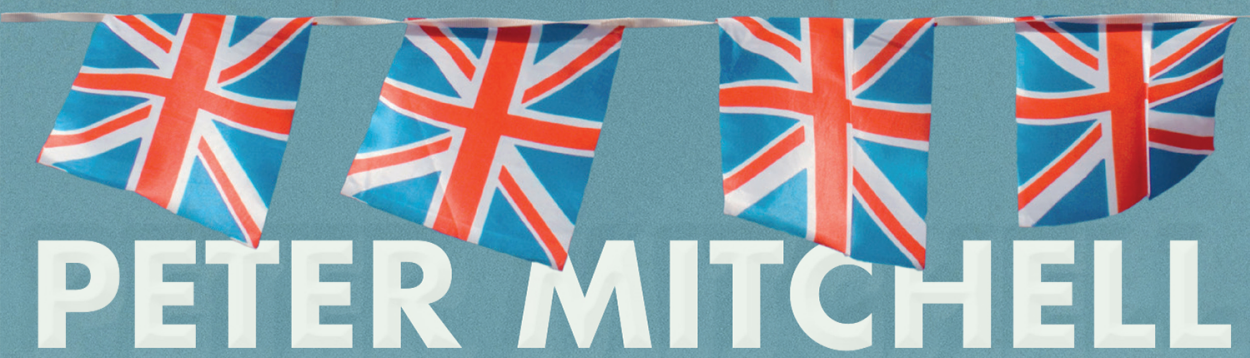

'An essential book for these disconcerting times.'

SATHNAM SANG HER Peter Mitchell - 9781526159168 


\section{Imperial nostalgia}

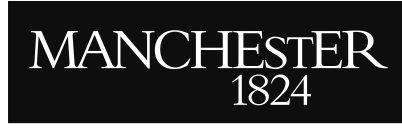

Manchester University Press 
Peter Mitchell - 9781526159168

Downloaded from manchesterhive.com at 04/26/2023 05:17:29AM 


\title{
Imperial nostalgia
}

How the British conquered themselves

\author{
Peter Mitchell
}

Manchester University Press 
Copyright (C) Peter Mitchell 2021

The right of Peter Mitchell to be identified as the author of this work has been asserted by them in accordance with the Copyright, Designs and Patents Act 1988.

Published by Manchester University Press

Oxford Road, Manchester M13 9PL

www.manchesteruniversitypress.co.uk

British Library Cataloguing-in-Publication Data

A catalogue record for this book is available from the British Library

ISBN 9781526161314 hardback

ISBN 9781526146205 paperback

First published 2021

The publisher has no responsibility for the persistence or accuracy of URLs for any external or third-party internet websites referred to in this book, and does not guarantee that any content on such websites is, or will remain, accurate or appropriate.

Cover image: opuscule / Alamy Stock Photo

Typeset By Newgen Publishing UK 